\title{
Seerbann und Getidtsbann
}

iiber bas wejen ber öfrentlidhen Gewalt

\author{
Bon \\ Brofeffoc Dr. iur. ef phil. Grid Jung
}

Sonderabbeud aus ber Jefitideift hï Brolefior Zraeger

1926

Berlagongedeg otilte, betin 
